\title{
PROTOTYPE AND IMAGE IN ST. MAXIMUS THE CONFESSOR'S THINKING AND ITS ACTUALITY
}

Mihai BURLACU*

\begin{abstract}
St. Maximus' Work is grounded by Chalcedonian doctrine in christological line, and by a sinthesis between neoplatonic philosophical terms and a Revelation contents in antropological views. Also St. Maximus has a propoer originality because he anticipated next great thematic controversy: the iconoclasm. Through many refferences on God like Archetyp and Its Image, in fact Man, he describe the found of intelligible Icon, videlicet man as alive icon of the Word's Person. But this anticipation will be constitute a method in theological gnoseology, specifically to eastern orthodox area, because it suppose the power of symbolic way of knowledge. From this, we show that the link between Prototype and Image can be expressed like the link between Symbol and its symbolized reality. In St. Maximus Work, we see all beings and facts in the light of this theory, such that all reality of creatural pleroma is founded on imagistic correlation, and from symbolistic meaning. In antropology, this question is called similarity between God and man; and this is a consacrated concept in itself. That fact has a current relevancy because modern theories of knowledge can not develope an wortly mode of correspondence between consciousness subjective world and phenomenal objective world. That cannot explicate if consciousness reflect reality in its genuine, but iconic knowledge can unravel this.
\end{abstract}

Keywords: antropology, hypostasis structure, compatibility, similarity, rationality meaning

*PhD Lecturer, University of Bucureşti (Faculty on Orthodox Theology), Romania. 


\section{Temporal placement of Image theology, in aknowledged form}

Image concept belongs from an old theology, with biblical roots, even in Hebraic thinking. This has a large development in Mosaic religion and esspecially in Christianity.

In Hebrew Period of Revelationship, corresponding to Old Testament, eikon concept was founded on Genesis text about making man: "Let us make man in our image, after our likeness... and God created man in his own image, in the image of God created him; male and female" (Genesis 1:26-27; American Standard Version Bible) ${ }^{1}$. Therminologically, "eikon" is an greek word, the equivalent of hebraic "tselem", which means "image". Along history, Image concept create more facts in many thinking systems or paradigmas, esspecially in platonic and aristotelic philosophy which purpose a similarity parallelism between this concrete world and idea's world. So similarity rule is not new, but very old, and extensive. It is an idea founded into many thinking systems, or in base of dualistic systems. In Christianity, we see image concept an affirmative manner of compatibility between God and man.

In New Testament, concept of Image and idea of similarity are affirmated even St. Apostle Paul (Romans 5:14; 8:29; Galatians 4:19; Philippians 2, 7; Colossians 1:15; 3:10; Hebrews 1:3) either between Crist and God, like Image of Father, or between man and God.

For that, man's value is based on this creatural fact, and it is emphasized by all early Church' Fathers.

Patristic period claims man, like Image of God, in Christological way, especially in East greek Christianity, while in latin culture, Image is understanded in structuralist mode like St. Augustin anthropology. In this, man is a similar being with God, in His treefold mode, but not threepersonalist. Eastern Fathers as like desert Fathers, conceives man like an icon of Christ, and similarity is defined by in terms of man becoming christomorphic. Also, we observe another meaning of Image, between Christ and Father, in which Crist as man is an image of God in the World. Of course, these Image meaning not conceive the subordination of Son, nor a crypto arianistic form, but only "iconomical" work of Christ as it

${ }^{1}$ Cf. Bible Works, v. 6.

${ }^{2}$ Enciclopedia iudaismului, Bucureşti, Hasefer, 2016, p. 256. 
was related by St. Paul in Philippians 2.

Main form of these concept was approached by the theology of St. Gregory of Nysse and especially St. Maximus the Confessor. They have complete vision about man and his relationship with God, fact which purpose a complete theory of man as Image of God, and God as Prototype of man.

In modern Christian Anthropology is established on Image concept and it develop a theology of eikon, means a similarity between God and man. Modern theology link patristic theory of Image and protoype, as well as is reached in St. Maximus work. Most theologians find in St. Maximus the Confessor, probable first signifiant point in christian anthropology $\mathrm{y}^{3}$; so that is the reason for we shall analize concepts of Image and Prototype in his work.

\section{Image idea before and after iconoclasm}

Iconoclasm represent along history, a controversy wich lead for definition of Image and Prototype concepts, because attest the posibility of potentiality level to reveal itself into concrecy. So all unseen things is manifested by all seened things, and invariably, uncreated energies of God get forms in all things which belong to perceptible plan of creation. That form is evidently an intelligible icon. So, icons as imagistic objects, defended on Iconoclastic crysis, behave an intelligibil matter for christian gnoseology because they certify posibility of strong revelation through forms.

Before iconoclasm, icon principle was appreciated by the Church, such that it was never challenged in early centuries. Holy Tradition records entire iconology, either as principle or as imaginal object. Beyond this tradition, contestation of icon and its properly Image precept appear from transcendental idea of incompatible God's being and creatural finite condition. This transcendence draws a new understanding of icon, and over opportunity of God's manifestation in creatural area. For this reason, some philosophies, especially islamic, declare icons as sacrilege. It's the case of byzantine emperors from isaurian dinasty, whose are trigered

3 John MeYendorfF, Christ in Eastern Christian Thought, N.Y, Vladimir's Seminary Press, 1975, p. 168. 
iconoclasm atitude and it's consequences in christian knowledge. These are founded on aristotelic theory of pure esences, where we distinguish separation between concrete things and theoretical or abstract things. In same way, islamic theology of these times purpose a strongly trancedence of God until His radical unknowability. Thereby, Revelation of God appear impossible, all the more Image concept.

From this point, St. John of Damascus defend holy icons, and implicitly conception of Image ${ }^{4}$. Next theology from this, after Seventh Ecumenical Council and St. Photius restoration from the time of iconoclastic crisis, will put significance of icons and Image theology in the front of peculiar orthodox of East. Thus, Image teaching with all implies, become the fundament of Orthodox Christianity.

\section{Types of Image}

It is very opportune to indicate that is exist many types of Image, because that teaching touch also many doctrinal direction of Orthodox Christianity. St. Gregory of Nyssa remark that Image is understanded in two ways. First, created stuffs constitues an image of uncreated, and second, each created reality may be image of other created reality ${ }^{5}$, such that entire World is a comunication mode of crypto-reality. In this way, Fr. Phd. Dumitru Stăniloae affirm the World is a God's reason plasticized.

St. John of Damascus synthesizes icons in two forms: sensitives and intelligibles ${ }^{6}$. So, those intelligibles in its acception leads to Image theology. It's knowed six types of icons, and it is possible to accepte a synonymy between icon as symbol and Image as concept. First icon shows Son as image of Father. Second type of icon reveals those seen to be image of those unseen. Third type of icon is man as image of God, but not in structural meaning so in christological. Fourth type of icon refears to symbol as modality of knowledge faithfull of God. Fifth mode of icon is that one prophetic function of actual things as image for thats future. And at last, sixth type of icon is knowed that anamnetically, where that

\footnotetext{
${ }^{4}$ Ioan G. COMAN, Patrologia, Mănăstirea Dervent, 2004.

${ }^{5}$ St. Gregory of NySSA, About Soul and Resurection, Bucureşti, Herald, 2006, p. 125.

${ }^{6}$ St. John OF DAmascus, Apologizing holy icons, Bucureşti, Institutul Biblic şi de Misiune Ortodoxă Ph, 2017, p. 128.
} 
present forms constitues images for those from past.

Afterwards, Leonid Uspensky's theology of icon present Image teaching in same manner as symbolic knowledge of God and His Revelation. His opinion develops Image concept like a symbol ${ }^{7}$. Instead the symbol on Unspensky's thinking is a modality to konw, so Image concept belongs to an epistemological instrumentary, with aplication on majority contexts.

\section{St. Maximus and Image idea}

Most of modern patrology experts believes that Image idea of St. Maximus the Confessor is inspired by St. Gregory of Nyssa, because many theories of him is founded on St. Maximus work. In the main, St. Maximus writings pleads for symbolic interpretation, where all things, objects, personalities or situations have a correspondency into inner spiritual life, in its bond with grace of Holy Spirit. That symbolic interpretation was called mystagogy, even by St. Maximus. In this is found many refferences for image concept.

These promote a bundle between man and God, between created being and uncreated, in which it is seen a great correspondence law from symbol to symbolized reality.

Image idea is a great theme on St. Maximus theology, because his main concern is one of knowledge of God, and entire world according to Him.

Main references of St. Maximus on image is founded on comentaries about first man in paradise ${ }^{8}$. Adam before falling embodies perfectly image of God. And definition of Image of God is reportable on this primordial condition.

Simultaneously, falling man lead to demage Image in man but this is not lost like in protestant conception. Fr. Dumitru Stăniloae, great interpreter of St. Maximus, said the Image of God in man is only darked.

Jesus Christ is the Prototype, not only in creatural meaning, but in redeemer meaning, who assume like Adam entire nature of man, in fact,

${ }^{7}$ Cf. Leonid UsPensky, Theology of Icon, Bucureşti, Anastasia, 1994, p. 118-120.

${ }^{8}$ St. Maximus the Confessor, “Ambigua”, in PSB 80, Bucureşti, Institutul Biblic şi de Misiune Ortodoxă Ph, 1983, p. 197. 
entire humankind really and recover it. After St. Maximus, Christ in His salvation work not only reinstate humankind at primordial status before falling, but He exceed this status, and place human nature in His Divine Person'. That fact implies many consequences for human beings because Christ include in his identity something created, and trinitarian relationships will be implies this in Son identity. Thus it is possible rescue of man, not only in first Adam as protoype or being destination, but in Jesus Christ as Second Adam Who places man in relation with Holy Trinity.

As much man be christomorphic, as Image is recreated.

\section{Image and rationality}

Theology of Middle Age exploit an ancient theory of rationality of creation. According to it, the world has a rationality and a compatibility in its componency each other. Rationality of creation was a main theme of St. Maximus the Confessor, who argued that creation is compatible with a universal Prototype namely Logos of God. This compatibility is the establishment for orthodox Cosmology, in opposition to scholastic theology, where creation or Cosmos is based on autonomy rules. In St. Maximus' theology, Cosmos or entire created world, is founded on Logos of God who maintain or support in existence all things. This is a theonomic vision of Cosmos, because World cannot develope or maintain in its existence by itself. So, presence of God with His uncreated energies is necessary both for accomplished existence in eternal life, and same for basic existence of Creation.

In his work Mystagogia, St. Maximus shows that rationality is foundament of creaturally act of God, that $\mathrm{He}$ intends to create, inclusivelly peculiar limits of each thing created and direction of it aspiration, so that it will come to be. Creatural rationality is an image of Logos intelligibility. In this case, Second Person of Holy Trinity is exemplary for reason of creaturely beings, and representative Prototype of it.

Rationality principle at St. Maximus implies the Image idea

9 St. Maximus the Confessor, Mystagogia, Bucureşti, Institutul Biblic şi de Misiune Ortodoxă Ph, 1997, p. 38. 
because it reflect relationship between God and man like it was presented in Divine Revelation. Rationality principle belongs not only to Christianity, it is encountered in many religious and thinking systems. From intelligible character of this world, along the low similarity, wisdom of God may be personalized and partially defined in Person of Son, meaning Logos of God.

St. Maximus confers a great importance of similarity between man and God, such as entire created world is hypostasied in him. Many modern theologians observe gretest rhole of man in creation which has a deeply anthropic character.

In vision of St. Maximus, rationality of man is supreme creaturely reason of created beings, because it is hypostasied in Person of Christ at His Incarnation at once ${ }^{10}$. So, human rationality is superior to all created reason, and this last is subscribed to first.

\section{Image and Cosmos}

Cosmic conception of St. Maximus are founded on image principle, because it has a deeply humanely peculiar. In Mystagogia St. Maximus insists about real vocation of creation to become as humankind likeness. And this allow the possibility that man be a paradigm for entire nature. St. Maximus resume St. Dionysius' the Areopagite conception of hierarchies in meaning all Cosmos is structured by hierarchy levels. That implies in St. Maximus' work various levels of relationship PrototypeImage. Just like God is prototype of man, and man image of God, same as created nature, structured in levels of being is image of man, and man is prototype of Cosmos. In fact, St. Maximus insists for capacity of Cosmos to resuming and symbolizing man, such as, Cosmos is an macroanthropos, and man is a micro-cosmos.

This correspondence between them is argued in ground of similarity which developes an Image principle.

So that it is exist two similarity modes, first between Cosmos and human paradigme, and second between Cosmos and Logos. These are two kind of thematic similarity of Image principle, but them not involve

${ }^{10}$ St. MAXimus the CONFessor, "Answers to Thalasius", in "Philocalia" (Romanian), Bucureşti, Institutul Biblic şi de Misiune Ortodoxă Ph, 2004, p. 76-78. 
a conflictual or divergent positions, because Logos of God is in same way a paradigm for humankind. From universality of Logos, it is deductible that man is crown of Cosmos is same measure he is christomorpfical. So, there are a direct proportionality, where image character of Cosmos towards man depends actually by degree of image character of man towards God. St. Maximus refers to currently of Image into similarity, showing that measure of similarity between Icon and Prototype in case of man and God, reveals similarity between man and Cosmos. In Bible we reached this idea through solidarity of nature with man in paradise, and dissociation nature by man after sin's falling.

St. Maximus considered man as icon of God in Earth, in creaturely seen world, so that is the reason for expounding Cosmos as image of man. We say that is an unique and great idea in patristics, for St. Maximus accord an special importance of Cosmos in order of salvation of man. For him, solidarity of Cosmos with man is a signal or symptom of solidarity of man with God. Out of all Church's Fathers, on St. Maximus that theory is very good articulated.

\section{Image and Similarity. Definition of time as distance from Image to Similarity}

There is a connection in St. Maximus work between Image and time as concept. That put a philosophical concept into a christian system, leading to what we call christian philosophy. For St. Maximus, time is distance from Image to Similarity. According St. Basil the Great, where Similarity is in fact livig Image, St. Maximus explain time on these biblical terms. For him, Image and Similarity describe the mouvement of being fact. For created beings have the mouvement as an intrisec character, and these been governed by becoming law.

St. Maximus establish a clarely formula of created beings: they must to passing by three stages: creation, mouvement or becoming, and stability. Creation is the first moment peculiar of created things, becoming is secondly, and stability describe the finality or destination of being fact. First moment is creation or coming from nothingness or nonexistence to existence. This is concomitant with an Image reason of created being to its Prototype. Third moment is finality, or moment in which creaturely being achieve maximal compatibility with its Prototype. 
Distance from one point to three represent actually the second moment: becoming. And becoming defines time, and it is called Similarity.

St. Gregorius of Nyssa deepens this theory before St. Maximus, but St. Maximus binds it to time concept.

In current dogmatics is impossible refering to Image without Similarity or reverse because Image implies Similarity in its definition.

\section{Posibility of iconic knowledge as method. Iconic gnoseology and its importance today}

St. Maximus the Confessor has opened a new perspective of God knowledge, in fact a new theological method. This consist in intuitive mode to knowledge, some part possible, and some part imposible, or in current language some apophatic and some cataphatic knowledge. But we talk about one single and unique kowledge in two dimensions: one known and other unknown.

Icon is a suggestion for knowlegde, because it is more precis than rational and discursive konowledge. Iconic knowledge is an intuitive fact and it is founded on inspiration of Holy Spirit. St. Maximus the Confessor insists on providence principle and on the fortly volition of God about this world. He says if God want something, anything is done in conformity with His will, because nature by his structure lead His will. In this fact, iconic knowledge purpose Image concept as modality to form a conception abot God and His Images: firstly man, and secondly creation nature in its rationality.

In Church dogmatics we are interested on peculiar method of dogmatic speeching and many direction of current theology provides a lot of possibilities of dogmatic discourses. But most of them lead proper methods of other scinces, in fact humanly and with empirical method. The knowledge purposed by icnonic method is better than other sciences and non-speculative; it is intuitive and based on Divine Revelation. Iconic knowledge is adressing for suggestion and for afective register of life, which implies entire life of man, not only intelligence ${ }^{11}$.

In this form knowledge is not only a cumulative information, but a life implication of person in relationship with God. So, by point view of

${ }^{11}$ Ștefan BuCHIU, Apophatic Knowlegde, București, Libra, 2002, p. 36. 
orthodox theology, we see knowledge like a participation, fact that overtalk any assimilation process.

Gnoseology is modern chapter of dogmatics who employ knowledge concept from Revelation perspective, and today is very exploited together with modern philisophical concerns. Fr. Dumitru Stăniloae insists on this kind of knowledge because it placed rational issue in mystical dimension of existence ${ }^{12}$.

Today it is necessary to establish a special form of theological speech, both on mystical and conctrete values for a authentic dogmatic vision.

\section{Icon like ritualic element, and its opportunity for knowledge theology of Image}

In history of Orthodox Church, is ecelebrating Sunday of Orthodoxy, that assume triumf of holy icons in context of iconoclast controversy. This association between icons and orthodoxy, develope a organic and insidly bundle of right faith achievable best in iconic conceptual form.

Practic life of Chruch in wich Grace of Holy Spirit is manifested over Church and world, prove will of Christ who lead Church as fundamental Bishop and world as Logos. Crowd of miracles maded through and recorded in Church memory, deposited in Holy Tradition is an argument for our encouragement to know God and His will, and do it starting from iconic mode of knowledge Him, which is based on Image idea. All ritual with its many symbols, analogies and other things whic purpose a intelligible way of perception, are grounded on this form of knowledge.

That is the reason to consider Image idea of Revelation and patristic like a premise for wortly perspective and vision of the reality. If actual systems ask theology for an endemic or vernacular vision, we can promote one iconic and imagistic perspective.

\section{References}

1. BuchIU, Ștefan, Cunoaşterea apofatică (Apophatic knowlegde), București, Libra, 2002.

12 Dumitru STĂNiloAe, Teologia Dogmatică (Dogmatic Theology), vol. I, Bucureşti, 2006, p. 86-89. 
2. Coman, Ioan G., Patrologia, Mănăstirea Dervent, 2004.

3. SAINT GRegory of NySSA, About soul and Resurection, Bucureşti, Herald, 2006.

4. SAINT John OF DAMASCus, Cele trei tratate contra iconoclaștilor (Treaties In Defense of Holy Images), Bucureşti, Institutul Biblic şi de Misiune Ortodoxă Ph, 2017.

5. SaInt Maximus The CONFessor, "Ambigua", in coll. "Părinți şi scriitori bisericești" (PSB), Bucureşti, Institutul Biblic şi de Misiune Ortodoxă Ph, 1983.

6. SAINT MAXIMUS THE CONFESSOR, "Răspunsuri către Thalasie (Answers to Thalasius)", in coll. Filocalia, Bucureşti, Institutul Biblic şi de Misiune Ortodoxă Ph, 2004.

7. SAINT MAXIMUS The CONFESSOR, Mystagogia, Bucureşti, Institutul Biblic şi de Misiune Ortodoxă Ph, 1997.

8. MEYENDORFF, John, Christ in Eastern Christian Thought, NY, Vladimir's Seminary Press, 1975.

9. StăniloAe, Dumitru, Dogmatic Theology, vol. I, Bucureşti, Biblic Institute and Mission of Orthodox Romanian Church, 2006, p. 86-89.

10. USPENSKY, Leonid, Theology of Icon, Bucureşti, Anastasia, 1994. 